\title{
PENGARUH MODEL PEMBELAJARAN ACCELERATED LEARNING TERHADAP KEMAMPUAN PENALARAN MATEMATIS SISWA DITINJAU DARI SELF REGULATED LEARNING
}

\author{
Nira Nawastiti ${ }^{1}$ Suyono $^{2}$ Wardini Rahayu ${ }^{3}$
}

\begin{abstract}
This study aims to see the effect of accelerated learning model of learning on the ability of mathematical reasoning in terms of self-regulated learning. This research was conducted at SMK Negeri Bekasi Regency in the academic year 2016/2017. The design of this research is Posttest-Only Control Design. The research method used is quasi experiment (quasi experiment). The reasonably affordable population of this study were four classes (two classes in two different schools, two classes at SMK Negeri 1 Tambun Selatan, which were treated with accelerated learning model and two classes at SMK Negeri 1 Tambun Utara were treated by conventional learning model) of the normal distribution, have the same or homogeneous variance, and have the same equality. The results of this study are (1) The mathematical reasoning ability of students who were treated with accelerated learning model is better than who where treated with the mathematical reasoning ability of students who were treated with conventional learning model, (2) there is interaction between learning model with self regulated learning to the ability of mathematical reasoning, (3) students' mathematical reasoning ability given treatment with accelerated learning model is better than who where treated with mathematical reasoning ability of students who are treated with learning model (4) The mathematical reasoning ability of students treated with conventional learning model is not better than who where treated with the mathematical reasoning ability of students who are treated with accelerated learning learning model.
\end{abstract}

Keywords: Mathematical Reasoning Ability, Self Regulated Learning, Accelerated Learning Model.

ABSTRAK: Penelitian ini bertujuan untuk melihat pengaruh model pember
accelerated learning terhadap kemampuan penalaran matematis ditinjau dari self regul
learning. Penelitian ini dilaksanakan di SMK Negeri Kabupaten Bekasi pada tahun pe
2016/2017. Desain penelitian ini adalah Posttest-Only Control Design. Metode penelitian
digunakan quasi eksperiment (eksperimen semu). Populasi terjangkau penelitian ini
empat kelas (masing masing dua kelas dalam dua sekolah yang berbeda yaitu dua kelas
SMK Negeri 1 Tambun Selatan yang diberi perlakuan model pembelajaran acce
learning dan dua kelas pada SMK Negeri 1 Tambun Utara diberi perlakuan
pembelajaran konvensional) yang berasal dari distribusi normal, memiliki varians
sama atau homogen, dan memiliki kesamaan rata - rata .Hasil penelitian ini adal
Kemampuan penalaran matematis siswa yang diberi perlakuan dengan model pembe
accelerated learning lebih baik dengan kemampuan penalaran matematis siswa yang
perlakuan model pembelajaran konvesional, (2) Terdapat interaksi antara
pembelajaran dengan self regulated learning terhadap kemampuan penalaran matematis
Kemampuan penalaran matematis siswa yag diberi perlakuan dengan model pembe
accelerated learning lebih baik dengan kemampuan penalaran matematis siswa yang
perlakuan model pembelajaran konvensional pada kelompok self regulated lear

${ }^{1}$ Mahasiswa Magister Pendidikan Matematika, Universitas Negeri Jakarta, Email:
nira.abdurrahim@gmail.com
${ }^{2}$ Dosen Magister Pendidikan Matematika, Universitas Negeri Jakarta
${ }^{3}$ Dosen Magister Pendidikan Matematika, Universitas Negeri Jakarta 
NIRA NAWASTITI, SUYONO, WARDINI RAHAYU

tinggi,(4) Kemampuan penalaran matematis siswa yang diberi perlakuan dengan model pembelajaran konvensional tidak lebih baik dengan kemampuan penalaran matematis siswa yang diberi perlakuan dengan model pembelajaran accelerated learning.

Kata Kunci: Kemampuan Penalaran Matematis, Self Regulated Learning, Model Pembelajaran Accelerated Learning.

\section{PENDAHULUAN}

Dalam proses pembelajaran kepada siswa, sepatutnya seorang guru mengetahui berbagai cara pengajaran matematika yang cocok untuk dilakukan. Peranan penerapan ini menuntut guru untuk berkreativitas dalam menentukan cara mengajar yang tepat melalui suatu metode, pendekatan maupun model pembelajaran. Seringkali seorang guru dalam pengajaran yang dilakukan itu tidak disadarinya bahwa telah melakukan suatu metode, pendekatan atau model pembelajaran dan tak jarang pula disadari guru dalam pengajarannya selalu monoton terhadap belajar mengajarnya sehingga pembelajarannya cenderung kaku, satu jalan dan verbal.

Tujuan pembelajaran matematika sekolah adalah penalaran pada pola sifat, melakukan generalisasi, memberikan alasan terhadap beberapa gagasan, menyajikan pernyataan matematika kemudian mengomunikasikan gagasan dengan simbol, tabel, diagram atau media lain untuk memperjelas keadaan atau masalah sehingga memiliki sikap menghargai kegunaan matematika dalam kehidupan, yaitu memiliki rasa ingin tahu, perhatian dan minat dalam mempelajari matematika, serta sikap ulet dan percaya diri dalam pemecahan masalah. Salah satu tujuan pembelajaran matematika adalah melatih cara berpikir dan bernalar dalam menarik kesimpulan. Materi matematika dan penalaran matematika merupakan dua hal yang tidak dapat dipisahkan, yaitu materi matematika dipahami melalui penalaran, dan penalaran dipahami dan dilatihkan melalui belajar materi matematika.

Penalaran adalah suatu proses atau aktivitas berpikir untuk menarik kesimpulan atau membuat pernyataan yang telah dibuktikan kebenarannya. Pembelajaran dengan penalaran deduktif atau induktif dengan maksud tujuan pembelajarannya agar siswa mengetahui proses demi proses ilmu yang didapatkan siswa tersebut. Pemberian pengajaran tersebut cukup efektif untuk diaplikasikan pada pelajaran matematika. Tetapi, ketika suatu pengajaran yang hanya mendoktrin siswa untuk lebih menghafal rumus dengan tidak memberikan konsep suatu sistem bagian yang harus dipelajari itu membuat siswa tidak permanen dalam pengingatannya dan siswapun tidak mengerti akan konsep dari materi yang diajarkan guru sehingga mengakibatkan pemanggilan memori terhadap pembelajaran dalam mengingat pembelajaran sebelumnya rendah.

Matematika yang tersusun dari berbagai macam materi yang disajikan sesuai dengan jenjang taraf pendidikannya selalu berkaitan. Siswa akan merasa kesulitan dalam mengerjakan permasalahan yang harus dikerjakan jika siswa tersebut tidak memahami proses pembelajaran karena tidak mengetahui konsep dari awal pengerjaannya dan melakukan proses demi proses yang diberikan indikasi oleh gurunya. Maka, kemampuan yang menjadi tujuan dalam pembelajaran matematika yang perlu dibekali yaitu kemampuan penalaran matematis siswa. Kemampuan penalaran matematis dalam pembelajaran akan membantu siswa dalam proses berfikir menyelesaikan permasalahan yang diberikan dengan tepat. 
NIRA NAWASTITI, SUYONO, WARDINI RAHAYU

Penalaran induktif merupakan proses berpikir untuk menarik suatu kesimpulan atau membuat suatu pernyataan baru yang bersifat umum berdasarkan pada beberapa pernyataan khusus yang diketahui benar. Penalaran deduktif berarti membuat beberapa kesimpulan logis berdasarkan informasi diberikan. Matematika dikenal sebagai ilmu deduktif, maka proses pengerjaan matematika bersifat deduktif. Maka, penalaran yang dimaksud dalam penelitian ini adalah kemampuan siswa dalam menalar dan mengkaitkan hubungan keserupaan dari hal yang berbeda untuk mengajukan dugaan dalam menyelesaikan permasalahan.

Menurut Utami,dkk (2014), kemampuan penalaran matematis adalah kemampuan memberikan alasan/bukti terhadap beberapa solusi. Kemampuan tersebut mengungkapkan yang sangat esensial untuk memahami matematika dan Bani (2011) menyatakan bahwa kemampuan penalaran matematis adalah kemampuan menentukan kesimpulan yang tepat dalam masalah yang ada. Kesimpulan yang didapat merupakan penalaran sifat, generalisasi dan gagasan.

Dari beberapa uraian mengenai kemampuan penalaran matematis, maka kemampuan penalaran matematis yang dimaksud adalah kemampuan berpikir menurut alur kerangka berpikir tertentu berdasarkan konsep atau pemahaman yang telah didapat sebelumnya. Kemudian konsep atau pemahaman tersebut saling berhubungan satu sama lain dan diterapkan dalam permasalahan baru sehingga didapatkan keputusan baru yang logis dan dapat dipertanggungjawabkan atau dibuktikan kebenarannya.

Berdasarkan uraian di atas indikator (aspek) kemampuan penalaran matematis yang peneliti gunakan yaitu (1) Kemampuan mengajukan dugaan. (2) Kemampuan membuat pernyataan baru. (3) Kemampuan menentukan pola hubungan diantara dua objek atau lebih. (4) Kemampuan memberikan alasan terhadap beberapa solusi. (5) Kemampuan menentukan kesimpulan.

Proses pembelajaran tersebut membutuhkan model yang tepat. Kesalahan menggunakan model, dapat menghambat tercapainya tujuan pendidikan yang diinginkan. Dampak yang lain adalah rendahnya kemampuan bernalar siswa dalam pembelajaran matematika. Hal ini, disebabkan karena dalam proses siswa kurang dilibatkan dalam situasi optimal untuk belajar, pembelajaran cenderung berpusat pada guru, dan klasikal. Selain itu siswa kurang dilatih untuk bekerja kelompok dalam menganalisis permasalahan matematika, jarang sekali siswa menyampaikan ide untuk menjawab pertanyaan bagaimana proses yang dianalogkan guru tersebut. Dari beberapa model pembelajaran, ada model pembelajaran yang menarik dan dapat memicu pemahaman dan penalaran siswa pada materi lebih cepat serta mengingat lebih lama yaitu model pembelajaran accelerated learning.

Model pembelajaran accelerated learning yang digunakan untuk menjelaskan suatu rangkaian model pembelajaran bermakna dalam upaya melihat pengaruh pada kemampuan penalaran matematis siswa terhadap permasalahan yang akan memberikan manfaat kepada siswa diantaranya menciptakan imajinasi kreatif siswa, membuat siswa terlibat total, menciptakan lingkungan belajar yang sehat, mempercepat dan memperkaya belajar, meningkatkan daya ingat dan performa, membangun masyarakat belajar yang efektif. Langkah model pembelajaran accelerated learning yang M.A.S.T.E.R yang diperkenalkan oleh Nicholl. Keenam langkah tersebut yaitu (Rose dan Nicholl, 2003) dengan kepanjangan singkatannya yaitu motivating your mind (memotivasi pikiran), acquiring information (memperoleh informasi), searching out the meaning (menyelidiki makna), triggering the memory (memicu ingatan), exhibiting what you know (memamerkan apa yang 
telah ketahui), reflecting how you have learned (merefleksikan bagaimana proses belajar yang telah dilakukan).

Azmi (2016) menyatakan bahwa self regulated learning mengacu pada perencanaan yang hati-hati dan monitoring terhadap proses kognitif dan afektif yang tercakup dalam penyelesaian tugas-tugas akademik yang berhasil dengan baik. SRL menempatkan pentingnya kemampuan seseorang untuk belajar disiplin mengatur dan mengendalikan diri sendiri, terutama bila menghadapi tugas-tugas yang sulit. Pada sisi lain SRL menekankan pentingnya inisiatif karena SRL merupakan belajar yang terjadi atas inisatif. Tandiling (2011) menyatakan bahwa self regulated learning adalah proses aktif dan konstruktif yaitu mendiagnosis kebutuhan belajar dengan mengatur dan mengendalikan kinerja, kognisi, motivasi dan perilaku untuk melihat kesulitan sebagai tantangan sehingga siswa dapat mengevaluasi proses dan hasil belajar dari pembelajaran. Menurut Mastuti (2006), self regulated learning merupakan kemampuan untk mengontrol cara belajarnya dengan langkah - langkah mengobservasi diri, menilai diri dan memberikan respon bagi dirinya sendiri.

Nicol (2005), menyatakan Self-regulated learning is an active constructive process whereby learners set goals for their learning and monitor, regulate, and control their cognition, motivation, and behaviour, guided and constrained by their goals and the contextual features of the environment. Dari pernyataan Nicol, self regulated learning adalah proses konstruktif yang aktif dimana peserta didik menetapkan tujuan belajar dan memantau, mengatur, dan mengendalikan kognisi, motivasi, dan perilaku, dibimbing dan dibatasi oleh tujuan dan fitur kontekstualnya lingkungan hidup.

Berdasarkan uraian di atas indikator self regulated learning yang peneliti gunakan yaitu (1) Memfokuskan konsep belajar (2) Inisiatif belajar (3)Menetapkan target belajar (4) Mengontrol belajarn (5)Memonitor kemajuan belajar (6) Evaluasi proses dan hasil belajar

Dari uraian tersebut, self regulated learning merupakan variabel moderator terhadap kemampuan penalaran matematis yang diberi perlakuan model pembelajaran accelerated learning dan konvensional. Adapun yang sudah meneliti model pembelajaran accelerated learning dan kemampuan penalaran matematis diantaranya hasil penelitian Amelia (2014) yang menunjukkan kemampuan koneksi matematika siswa diberi perlakuan model pembelajaran accelerated learning lebih baik daripada siswa diberi perlakuan model pembelajaran konvensional. Kemudian hasil penelitian Amelia (2015) yang menunjukkan kemampuan pemecahan masalah matematis yang memperoleh pembelajaran accelerated learning lebih baik diibandingkan dengan siswa yang memperoleh pembelajaran konvensional. Selanjutnya, Hunaeni (2013) menunjukkan bahwa peningkatan kemampuan penalaran matematis siswa melalui pembelajaran SSCS (Search, Solve, Create and Share) lebih baik daripada siswa yang mendapat pembelajaran konvensional.

\section{METODE PENELITIAN}

Penelitian ini dilaksanakan di SMK (Sekolah Menengah Kejuruan) Negeri Kabupaten Bekasi, Provinsi Jawa Barat dengan unit analisis para siswa/i SMK Negeri 1 Tambun Selatan Kabupaten Bekasi dan SMK Negeri 1 Tambun Utara kelas XI Administrasi Perkantoran. Metode yang digunakan dalam penelitian ini adalah metode quasi eksperimen. Design penelitian ini adalah Postest - Only Control Design 
NIRA NAWASTITI, SUYONO, WARDINI RAHAYU

yaitu data yang diambil berupa hasil tes kemampuan penalaran matematis diakhir pembelajaran.

Populasi yang dimaksud dalam penelitian ini adalah seluruh siswa kelas XI SMK Negeri di Kabupaten Bekasi pada semester genap pada tahun pelajaran 2016/2017. Teknik pengambilan sampel dengan multistage random sampling. Hasil pemilihan sampel secara acak menetapkan kelas XI AP 1 dan 2 di SMK Negeri 1 Tambun Selatan dengan siswa sejumlah 80 orang sebagai kelompok eksperimen yang diberi perlakuan model pembelajaran accelerated learning. Kelas XI AP 1 dan 2 di SMK Negeri 1 Tambun Utara dengan siswa sejumlah 80 orang sebagai kelompok kontrol yang diberi perlakuan model pembelajaran konvensional.

Variabel bebas berupa model pembelajaran accelerated learning, variabel terikat berupa kemampuan penalaran matematis dan variabel moderator berupa self regulated learning. Teknik pengumpulan data yang digunakan dalam penelitian ini adalah kuisioner dan tes matematika. Validitas instrument kemampuan penalaran matematis dan self regulated learning menggunakan korelasi produk momen dari Pearson da reliabilitasnya menggunakan Alpha Conbrach. Analisis data pada penelitian dengan menggunakan uji $t$. Sebelum dilakukan analisis data, maka dilakukan uji normalitas menggunakan uji Kolmogorov-Smirnov dan uji homogenitas dengan uji Levene's.

\section{HASIL DAN PEMBAHASAN}

Pelaksanaan model pembelajaran dikelas eksperimen dilakukan oleh peneliti di SMK Negeri 1 Tambun Selatan dan di kelas kontrol dilakukan oleh guru matematika yaitu Ibu Sri Wahyuningsih, S.Pd di SMK Negeri 1 Tambun Utara. Melalui kegiatan model pembelajaran accelerated learning inilah memungkinkan kemampuan penalaran matematis siswa dipicu oleh rancangan pembelajaran pada model pembelajaran accelerated learning (Motivating Your Mind, Acquiring The Information, Searching Out The Meaning, Tiggering The Memory, Exhibiting What You Know, Reflecting How You've Learned). Alasan penggunaan model pembelajaran accelerated learning karena pada tahap aksi penalaran matematis siswa dimulai dari pada langkah Searching Out The Meaning yang mana guru memberikan Lembar Aktivitas Siswa (LAS) dan siswa menemukan sendiri penyelesaiannya kemudian memaknai maksud dari kesimpulan penyelesaian masalah yang diberikan terkait dengan materi yang diajarkan pada pertemuan tersebut.

Pengerjaan LAS dilakukan secara diskusi, siswa menguji dirinya sendiri, memperbaiki diri sendiri yang memiliki pengetahuan yang penuh mengenai bahan pelajaran. Setelah mencoba mendiskusikan materi dan LAS tersebut dengan teman kelompoknya, mempersentasikannya dan mencoba mengajarkannya dengan teman kelompoknya maupun teman kelompok lainnya yang membutuhkan bantuannya. Guru memposisikan diri sebagai fasilitator untuk meluruskan konsep materi, jawaban yang belum tepat dalam pengerjaan Lembar Aktivitas Siswa (LAS) dan mengarahkan kelompok yang membutuhkan bantuan penalaran untuk mencari penyelesaian masalah ke kelompok yang sudah mampu menalar terlebih dahulu. Berikut akan disajikan gambar aktivitas siswa dikelas uji coba. 


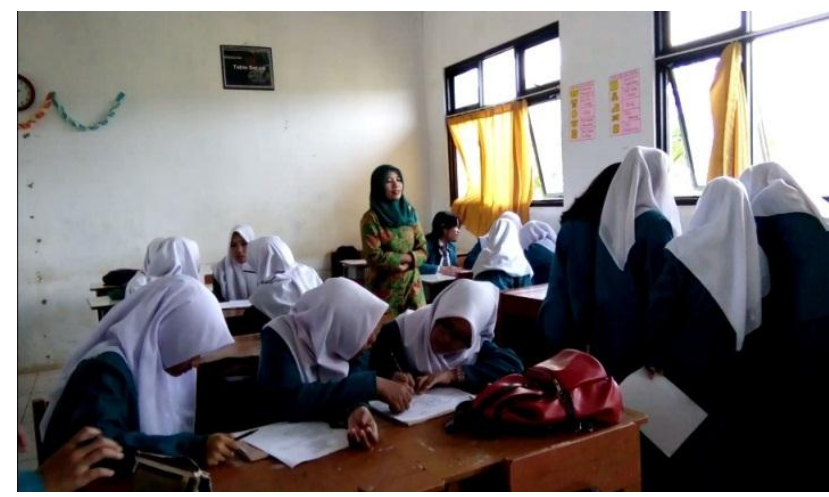

\section{Gambar 1. Aktivitas Siswadi Kelas Uji Coba}

Berdasarkan penjelasan tersebut, memberikan gambaran bahwa model pembelajaran accelerated learning yang diterapkan berpengaruh terhadap kemampuan penalaran matematis. Hal ini disebabkan model pembelajaran accelerated learning memberi ruang kepada siswa untuk mencari makna pembelajaran dengan memperoleh pengetahuannya secara mandiri maupun kelompoknya. Hal ini sejalan dengan penelitian yang dilakukan oleh Amelia (2015) telah meneliti tentang pengaruh model pembelajaran accelerated learning terhadap kemampuan matematis dengan hasil kemampuan matematis siswa yang memperoleh pembelajaran accelerated learning lebih baik dibandingkan dengan siswa yang memperoleh pembelajaran konvensional karena pada tahapan mempersentasikan dan aktivasi melatih siswa dalam mengembangkan kemampuan matematisnya. Penelitian lain yang dilakukan oleh Nugraha (2016) meneliti tentang pengaruh penerapan model pembelajaran accelerated learning terhadap peningkatan kemampuan matematis dengan kesimpulan bahwa peningkatan kemampuan matematis siswa yang mendapatkan pembelajaran konvesional, serta siswa bersikap positif terhadap penggunaan model accelerated learning lebih baik daripada model konvensional dalam pembelajaran matematika.

Tabel 1

Hasil Uji-t Perbedaan Kemampuan Penalaran Matematis Antara Model Pembelajaran

Independent Samples Test

\begin{tabular}{|l|l|l|l|l|l|l|l|}
\hline & \multicolumn{2}{|l|}{$\begin{array}{l}\text { Levene's Test } \\
\text { for Equality of } \\
\text { Variances }\end{array}$} & \multicolumn{5}{|l|}{ t-test for Equality of Means } \\
\cline { 2 - 7 } & F & Sig. & T & df & $\begin{array}{l}\text { Sig. (2- } \\
\text { tailed) }\end{array}$ & $\begin{array}{l}\text { Mean } \\
\text { Differen } \\
\text { ce }\end{array}$ & $\begin{array}{l}\text { Std. Error } \\
\text { Difference }\end{array}$ \\
\hline $\begin{array}{l}\text { Equal } \\
\frac{\pi}{\bar{z}} \begin{array}{l}\text { variances } \\
\text { assumed }\end{array}\end{array}$ & 1.157 & .285 & 5.368 & 102 & .000 & 6.51923 & 1.21450 \\
\hline
\end{tabular}


NIRA NAWASTITI, SUYONO, WARDINI RAHAYU

\begin{tabular}{|c|c|c|c|c|c|}
\hline $\begin{array}{l}\text { Equal } \\
\text { variances } \\
\text { not } \\
\text { assumed }\end{array}$ & 5.368 & \begin{tabular}{|l}
99.02 \\
6
\end{tabular} & .000 & 6.51923 & 1.21450 \\
\hline
\end{tabular}

Berdasarkan hasil perhitungan uji-t terlihat bahwa siswa yang diberi perlakuan model pembelajaran accelerated learning dan model pembelajaran konvensional diperoleh $t_{\text {hitung }}=5.368>t_{\text {tabel }}=1.65993$ berarti hipotesis $\mathrm{H}_{0}$ ditolak. Simpulannya adalah terdapat perbedaan kemampuan penalaran matematis antar model pembelajaran konvensional. Hal ini menyatakan bahwa kemampuan penalaran matematis siswa yang diberi perlakuan model pembelajaran accelerated learning lebih tinggi dibandingkan kemampuan penalaran matematis siswa yang diberi model pembelajaran konvesional.

\section{Pengaruh Interaksi Antara Model Pembelajaran dengan Self Regulated Learning Terhadap Kemampuan Penalaran Matematis}

Berdasarkan pemaparan diatas faktor interaksi antara model pembelajaran dengan self regulated learning menimbulkan pengaruh interaksi. Hal ini dapat dilihat pada faktor interaksi antara model pembelajaran dengan self regulated learning menimbulkan adanya pengaruh interaksi.hal ini dapat dilihat pada faktor interaksi anatara self regulated learning dengan model pembelajaran diperoleh nilai Sig $=0.024<0.05$ pada taraf signifikansi $\alpha=0.05$. Hal ini berarti bahwa terdapat interaksi yang signifikansi antara faktor model pembelajaran dan terhadap self regulated learning kemampuan penalaran matematis.

Dapat disimpulkan bahwa interaksi terjadi jika model pembelajaran dan self regulated learning secara bersama - sama memberikan pengaruh yang signifikan terhadap kemampuan penalaran matematis. Hal ini menggambarkan bahwa kemampuan penalaran matematis dipengaruhi oleh self regulated learning yang dimiliki siswa dan perlakuan yang diberikan guru yaitu model pembelajaran accelerated learning. Penggunaaan model pembelajaran bergantung kepada self regulated learning. Unutuk lebih jelasnya, akan divisualisasikan melalui gambar 1 grafik estimated marginal means of score di bawah ini.

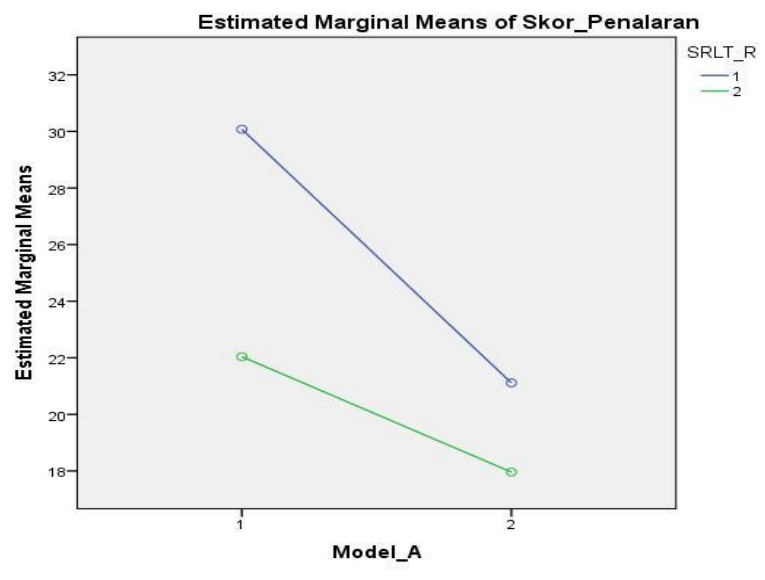

Gambar 2. Grafik Estimated Marginal Means of Skor 
NIRA NAWASTITI, SUYONO, WARDINI RAHAYU

Berdasarkan Gambar 2 bahwa terdapat interaksi antara model pembelajaran dan self regulated learning terhadap kemampuan penalaran matematis siswa. Hal ini ditandai dengan grafik garis yang tidak saling sejajar atau dengan kata lain garis tersebut memiliki gradient yang berbeda, maka dapat dikatakan bahwa grafik garis tersebut memiliki interaksi. Grafik di atas menunjukkan bahwa model pembelajaran accelerated learning cocok digunakan pada kelompok siswa memiliki self regulated learning tinggi. Hal ini terlihat dari grafik garis di atas bahwa kelompok sisa yang diberi perlakuan model pembelajaran accelerated learning lebih tinggi dibandingkan siswa yang diberi perlakuan model pembelajaran konvensioanal lebih tinggi dibandingkan siswa yang diberi perlakuan model pembelajaran konvensional pada kelompok self regulated learning tinggi karena dipicu oleh bahan ajar yang terdapat dalam model pembelajaran accelerated learning yaitu Lembar Aktivitas Siswa (LAS) yang merupakan aktivitas siswa yang mampu menalar siswa secara mandiri. Aksi terulang kembali ketika diskusi kelompok yang mampu menguji kemampuan penalaran matematis. Kegiatan yang berulang - ulang ini mampu membentuk teknik belajar yang terbaik bagi diri siswa, sehingga siswa dapat memantapkan kemampuan penalaran matematisnya.

\section{Kemampuan Penalaran Matematis pada Kelompok Siswa yang Memiliki Self Regulated Learning Tinggi}

Hipotesis penelitian yang ketiga adalah untuk menguji pengaruh sederhana (simple effect) dari kemapuan penalaran matematis siswa yang memiliki self regulated learning tinggi diberi model pembelajaran accelerated learning lebih tinggi dibandingkan dengan kelompok siswa yang diberi model pembelajaran konvensional. Berdasar Tabel 4.16 terdapat interaksi terhadap kemampuan penalaran matematis. Kelompok mana yang berikteraksi dengan model pembelajaran akan dilanjutkan dengan uji-t. hasil perhitungan uji-t dapat dilihat pada tabel berikut ini:

Tabel 2

Hasil Uji-t Perbedaan Kemampuan Penalaran Matematis pada Kelompok Siswa yang Memiliki Self Regulated Learning Tinggi

Independent Samples Test

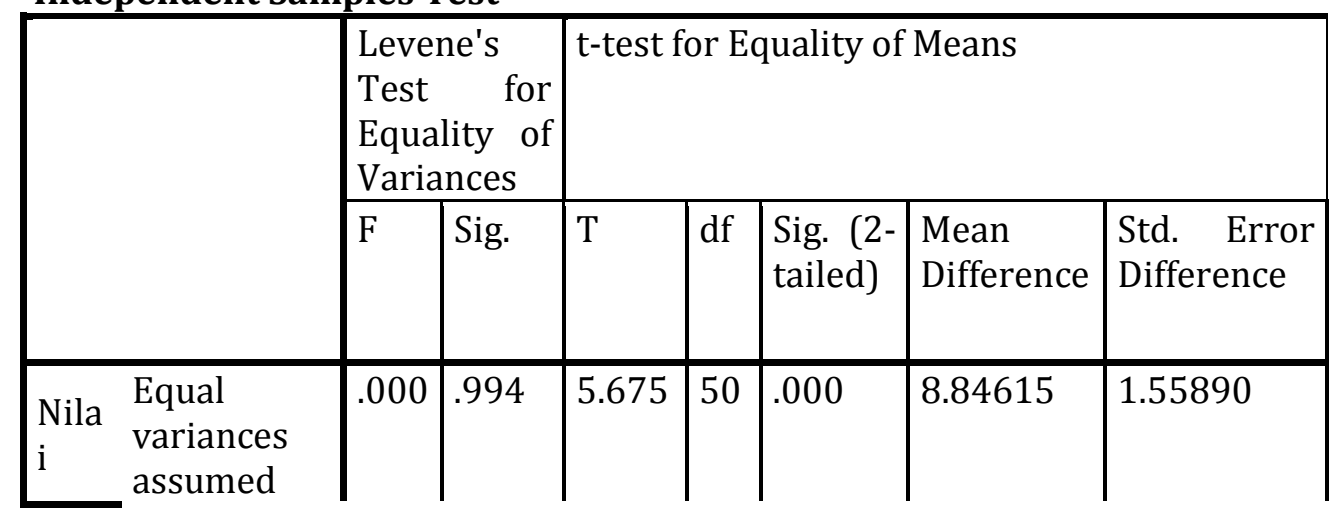


NIRA NAWASTITI, SUYONO, WARDINI RAHAYU

\begin{tabular}{|c|c|c|c|c|c|}
\hline $\begin{array}{l}\text { Equal } \\
\text { variances } \\
\text { not } \\
\text { assumed }\end{array}$ & 5.675 & $\begin{array}{l}49 \\
.7 \\
94\end{array}$ & .000 & 8.84615 & 1.55890 \\
\hline
\end{tabular}

Berdasarkan hasil perhitungan uji-t terlihat bahwa siswa yang diberi perlakuan model pembelajaran accelerated learning dan model pembelajaran konvesional pada kelompok kemampuan awal matematika tinggi diperoleh $\mathrm{t}_{\text {hitung }}=$ 5.675 sedangkan pada taraf signifikan $\alpha=0.05$ dengan $\mathrm{dk}=50$ bila dicocokkan dengan nilai $t_{\text {tabel }}=1.67591$ (perhitungan palda lampiran 5) berate hipotesis penelitian $\mathrm{H}_{0}$ ditolak.Simpulannya adalah terdapat perbedaan kemampuan penalaran matematis pada siswa yang diberi perlakuan model pembelajaran accelerated learning dengan siswa yang diberi perlakuan model pembelajaran konvensional pada kelompok yang memiliki self regulated learning tinggi. Hal ini menunjukkan bahwa kemampuan penalaran matematis siswa yang diberi perlakuan model pembelajaran accelerated learning lebih tinggi dibandingkan siswa yang diberi model pembelajaran konvensional pada kelompok yang memiliki self regulated learning tinggi.

Siswa berkemampuan self regulated learning tinggi yang diberi perlakuan model pembelajaran accelerated learning mampu mengembangkan dan mendorong kemampuan penalaran matematisnya, sehingga pembelajaran lebih bermakna. Self regulated learning tinggi menjadikan daya berpikir siswa lebih terampil dan membentuk siswa dengan sigap untuk menyelesaikan permasalahan yang akhirnya dapat mengembangkan kemampuan penalaran matematis.

\section{Kemampuan Penalaran Matematis pada Kelompok Siswa yang Memiliki Self Regulated Learning Rendah}

Hipotesis penelitian yang keempat adalah menguji pengaruh sederhana (simple effect) dari kemampuan penalaran matematis siswa yang memiliki self regulated learning rendah diberi model pembelajaran accelerated learning lebih rendah dibandingkan dengan kelompok sswa yang diberi model pembelajaran konvensional. Berdasar tabel 1 terdapat interaksi antara model pembelajaran dan self regulated learning terhadap kemampuan penalaran matematis. Kelompok mana yang berinteraksi dengan model pembelajaran akan dilanjutkan dengan uji-t. hasil perhitungan uji-t dapat dilihat pada tabel berikut ini.

Tabel 3

Hasi Uji-t Perbedaan Kemampuan Penalaran Matematis pada Kelompok Siswa yang Memiliki Self Regulated Learning Rendah

Independent Samples Test

\begin{tabular}{|l|l|l|l|l|l|l|l|}
\hline & $\begin{array}{l}\text { Levene's Test } \\
\text { for Equality of } \\
\text { Variances }\end{array}$ & \multicolumn{3}{|l|}{ t-test for Equality of Means } \\
\hline F & Sig. & T & df & $\begin{array}{l}\text { Sig. (2- } \\
\text { tailed) }\end{array}$ & $\begin{array}{l}\text { Mean } \\
\text { Difference }\end{array}$ & $\begin{array}{l}\text { Std. Error } \\
\text { Difference }\end{array}$ \\
\hline
\end{tabular}


NIRA NAWASTITI, SUYONO, WARDINI RAHAYU

\begin{tabular}{|c|c|c|c|c|c|c|c|c|}
\hline Nilai & $\begin{array}{l}\text { Equal } \\
\text { variances } \\
\text { assumed } \\
\text { Equal } \\
\text { variances } \\
\text { not } \\
\text { assumed }\end{array}$ & .168 & .684 & 2.812 & $\begin{array}{l} \\
49 \\
.8 \\
61\end{array}$ & .007 & 4.07692 & 1.44963 \\
\hline
\end{tabular}

Berdasarkan hasil perhitungan uji-t terlihat bahwa siswa yang diberi perlakuan model pembelajaran accelerated learning dan model pembelajaran konvensional pada kelompok self regulated learning rendah diperoleh $t_{\text {hitung }}=2.812$ sedangkan taraf signifikansi $\alpha=0.05$ dengan $\mathrm{dk}=50$ bila dicocokkan dengan nilai $t_{\text {tabel }}=-1.67591$. Karena $t_{\text {hitung }}=2.812>t_{\text {tabel }}=-1.67591$ (perhitungan pada lampiran 5) berarti hipotesis penelitian $\mathrm{H}_{0}$ diterima. Simpulannya adalah tidak terdapat perbedaan kemampuan penalaran matematis siswa yang diberi perlakuan model pembelajaran accelerated learning dengan siswa yang diberi model pembelajaran konvensional pada siswa yang memiliki self regulated learning rendah.

Ini berkaitan dengan pola pembelajaran secara mandiri yang tidak efektif sehingga dalam pembelajaran ketika membutuhkan bantuan seseorang maka seseorang tersebut menjadi tumpuannya (pionir) bukan menjadi partner dalam memahami materi yang diberikan. Aktivitas dalam pembelajaran untuk memahami konsep akan membebankan siswa dengan SRL rendah. Hal ini dikarenakan, model pembelajaran accelerated learning membutuhkan partisipasi aktif siswa untuk membangun sendiri pengetahuannya. Sementara kemampuan penalaran matematis terhadap pemahaman siswa kepada akan terjadi apabila siswa tersebut sudah sadarnya siswa terhadap kemandirian belajarnya yang mengerti untuk menemukan pola pembelajaran dalam pemahaman pada materi tersebut.

Hasil perhitungan deskripsi data menunjukkan bahwa pada kelompok self regulated learning redah dengan rata - rata kemampuan penalaran matematis pada siswa yang diajar dengan model pembelajaran accelerated learning sebesar 22, sedangkan rata - rata siswa yang diajar dengan model pembelajaran konvensional sebesar 17.6. Hal ini menunjukkan bahwa siswa yang diberi perlakuan model pembelajaran accelerated learning memiliki rerata lebih tinggi dibandingkan siswa yang diberi perlakuan model pembelajaran konvensional pada kelompok self regulated learning rendah. Kenyataan ini dapat dijelaskan melalui beberapa alasan bahwa model pembelajaran accelerated learning bertujuan untuk membentuk teknik belajar yang terbaik bagi siswa dan membentuk siswa dengan sigap menyelesaikan masalah yang diberikan guru. Berikut disajikan hasil jawaban siswa berkemampuan rendah terhadap tes kemampuan penalaran matematis. Meir (dalam Mertayasa, 2014) menyatakan model pembelajaran accelerated Learning adalah belajar melibatkan seluruh pikiran dan tubuh, belajar adalah berkreasi bukan mengkonsumsi, kerja sama membantu proses belajar, pembelajaran berlangsung pada banyak tingkatan secara simultan, belajar berasal dari mengerjakan pekerjaan itu sendiri setelah melakukan diskusi, emosi positif sangat membantu proses pembelajaran. Berikut disajikan hasil jawaban berkemampuan rendah terhadap tes kemampuan penalaran matematis pada soal nomor 1 


\section{Pengaruh Model Pembelajaran Accelerated Learning Terhadap Kemampuan Penalaran Matematis Siswa Ditinjau Dari Self Regulated Learning}

NIRA NAWASTITI, SUYONO, WARDINI RAHAYU

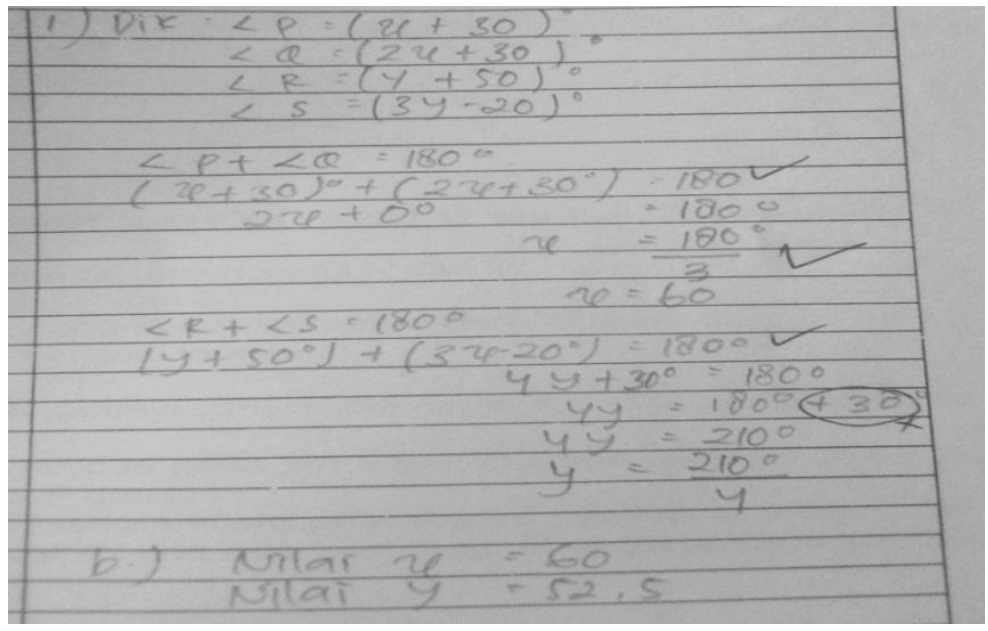

Gambar 3

Hasil jawaban siswa untuk skor 3

Berdasarkan hasil jawaban siswa pada gambar pada 4.7 sebanyak $46 \%$ siswa yang diberi perlakuan model pembelajaran accelerated learning pada kelompok self regulated learning rendah memperoleh skor 3 sedangkan 23\% siswa yang diberikan model pembelajaran konvensional pada kelompok self regulated learning rendahmemperoleh skor 3. Hal ini didukungoleh penelitian Sucitari, dkk (2013) menunjukkan bahwa penerapan modelpembelajaran accelerated learning mengurangi kesalahan sisa dalam enjawab soal dan meningkatkan hasil belajar siswa.

\section{KESIMPULAN}

1. Kemampuan penalaran matematis siswa yang diberi perlakuan dengan model pembelajaran accelerated learning lebih baik dengan kemampuan penalaran matematis siswa yang diberi perlakuan model pembelajaran konvesional

2. Terdapat interaksi antara model pembelajaran dengan self regulated learning terhadap kemampuan penalaran matematis.

3. Kemampuan penalaran matematis siswa yag diberi perlakuan dengan model pembelajaran accelerated learning lebih baik dengan kemampuan penalaran matematis siswa yang diberi perlakuan model pembelajaran konvensional pada kelompok self regulated learning tinggi.'

4. Kemampuan penalaran matematis siswa yang diberi perlakuan dengan model pembelajaran konvensional tidak lebih baik dengan kemampuan penalaran matematis siswa yang diberi perlakuan dengan model pembelajaran accelerated learning.

\section{DAFTAR PUSTAKA}

Amelia, S. (2014). The Influence Of Accelerated Learnng On Junior High School Students' Mathematics Connection Abilities. Procedding. Riau.

Amelia, S. (2015). Pengaruh Accelerated Learning Terhadap Kemampuan Pemecahan Masalah Matematis Siswa SMP. Procedding. Riau. 
NIRA NAWASTITI, SUYONO, WARDINI RAHAYU

Rose, C. (2003). Accelerated Learning. UK: Edu Science.

Nugraha, M. Gilang A. (2016). Pengaruh Penerapan Model Accelerated Learning terhadap Pengingkatan Kemampuan Koneksi Matematis Siswa SMP. Skripsi: Bandung

Mertayasa. (2014). Implementasi Model Pembelajaran Accelerated Learning Untuk Meningkatkan Hasil Belajar Ilmu Pengetahuan Alam Pada Siswa Kelas V Sekolah Dasar Negeri Dencarik Kabupaten BulelengTahun Pelajaran 2013/2014. Jurnal: Bali.

Sucitari. 2013. Model Pembelajaran Accelerated Learning Berfasilitas Multimedia Berpengaruh Terhadap Hasil Belajar IPA Siswa Kelas V SD Gugus III Kecamatan Semapura. Jurnal: Bali.

Mudjiman. 2007. Belajar Mandiri. Surakarta: UNS PRESS.

Hunaeni. (2013). Upaya Meningkatkan Kemampuan Penalaran Matematis Siswa SMP Melalui Model Pembelajaran Search, Solve, Create and Share. Skripsi: Bandung.

Utami, N. P. (2014). Kemampuan Penalaran Matematis Siswa Kelas XI IPA SMAN 2 Painan Melalui Penerapan Pembelajaran Think Pair Square. UNP: FMIPA.

Tandililing, E. (2011). The Enhancement of Mathematical Communication and Self Regulated Learning of Senior High School Students Through PQ4R Strategy Accompanied by Refutation Text Reading. Proceeding. Pontianak.

Azmi, (2016). Self Regulated Learning Salah Satu Modal Kesuksessan Belajar dan Mengajar. Seminar Asean $2^{\text {nd }}$ Psychology Humanity: Malang. 